\title{
СЕНЕГАЛ И ГВИНЕЯ-БИСАУ В 2000-е ГОДЫ: ОТ АЛЬЯНСА К КОНФРОНТАЦИИ
}

\begin{abstract}
Аннотация. Используя метод исторической реконструкции, автор анализирует изменения, произошедшие в отношениях двух соседних стран Западной Африки в связи с приходом к власти нового сенегальского президента Абдулая Вада. Дипломатический талант нового лидера позволил кардинально изменить вектор этих отношений в пользу Сенегала. Объектом исследования стали изменения во внутренней и внешней политике Сенегала и Гвинеи-Бисау в 2000-е гг., а также динамика конфликта в регионе Казаманс в этот период. Этот южный регион Сенегала, территориально, культурно и исторически тяготеющей к Гвинее-Бисау, на протяжении десятилетий остается главным фактором, влияющим на отношения двух стран. Предметом исследования автора стали факторы формирования и последующего распада сенегало-бисайского политического альянса. Автор приходит к выводу, что успехам А. Вада в установлении в Бисау сенегальского влияния в первой половине 2000-х г2. способствовали сильнейший экономический кризис и политическая изолячия Гвинеи-Бисау. Методологической основой исследования является системный, структурно-функциональный, сравнительно-политический подходы, методы анализа, синтеза, индукции, дедукции, наблюдения. К 2009 г., после очередной смены власти в Гвинеи-Бисау, диверсификации внешнеполитических связей страны и постепенной переориентацией ее на Анголу, Сенегал утрачивает здесь свое влияние. В настоящее время отношения двух стран вновь переживают кризис. Однако нерешенная проблема Казаманса будет и в дальнейшем заставлять лидеров двух стран искать пути для преодоления противоречий.
\end{abstract}

Ключевые слова: Сенегал, Гвинея-Бисау, Казаманс, альянс, дипломатия, Западная Африка, ДДСК, повстанцы, сепаратизм, военный переворот.

Review: Using the method of historical reconstruction, E. Khabenskaya analyzes the changes in the relations changes between two neighboring West African countries in connection with the new Senegalese President Abdoulaye Wade coming to power. Diplomatic talents allowed the new leader to change radically the vector of these relationships in favor of Senegal. The changes in Senegal and Guinea-Bissau internal and foreign policy in the 2000s., as well as the dynamics of the Casamance conflict in this period, compose the object of the study. This Senegal's southern region, geographically, culturally and historically linked to Guinea-Bissau, for decades has been the main factor in the relations between two countries. Factors of the formation and the subsequent collapse of the Senegal-Guinea-Bissau political alliance is the subject of the research. The author concludes that the strongest economic crisis and political isolation of Guinea-Bissau contributed to Wade's success in the establishment of Senegal's influence in Bissau in the first half of the 2000s. The methodolody of the research includes the systems approach, the structural-functional and comparative-political approaches, the methods of analysis, synthesis, induction, deduction and observation. By 2009, Senegal had lost its influence in Bissau after another government change in this country, which led to Guinea-Bissau's foreign relations diversification and its gradual reorientation to Angola. At present, the relations betwen these two countries are in crisis again. However, the unsolved problem of the Casamance will continue to force both leaders to seek the ways to overcome the contradictions.

Keywords: rebels, MFDC, West Africa, diplomacy, alliance,, Casamance, Guinea-Bissau, Senegal,, separatism, military coup.

П осле «войны 7 июня» (военный переворот в Бисау 7 июня 1998 г.), во время которой сенегальские войска, по просьбе свергнутого президента Ж. Виейры, вошли в Гвинею-Биcay, чтобы вернуть власть опальному лидеру, отношения между Дакаром и Бисау, казалось, были испорчены надолго. Операцию «Габу» значительная часть населения Гвинеи-Бисау восприняла враждебно и расценивала как военную интервенцию Сенегала [1]. В ситуации, когда большинство граждан РГБ и почти вся армия были на стороне опального генерала Мане, оказание поддержки утратившему общественное доверие президенту Виейре само по себе уже воспринималось как антинародная акция. Когда же сенегальское правительство объективно начало препятствовать попыткам мирного урегулирования конфликта уровень народного гнева просто зашкалил [2]. Выражением отношения гвинейцев к сенегальской «демократической» операции стало разграбление в мае 1999 г. посольства этой страны в Бисау. После победы «антипрезидентской коалиции» в РГБ формирование нового правительства из сторонников Мане и противников Виейры, очевидно, не долж- 
но было способствовать сближению двух стран в обозримой перспективе. Однако приход к власти в Сенегал Абдулая Вада в 2000 г. неожиданно кардинально меняет ситуацию в отношениях Сенегала и Гвинеи-Бисау.

Когда вновь избранный президент совершил свою первую поездку в Бисау в апреле 2000 г. ситуация между двумя странами была очень напряженной. По окончании «войны 7 июня» на границе участились вылазки бойцов Движения демократических сил Казаманса (ДДСК). Отдельные боевые группы непонятного подчинения устраивали налеты с целью мародерства на мирные деревни. В кражу скота в приграничных населенных пунктах Казаманса были вовлечены солдаы гвинейской армии (вероятно, в период межвластия в Бисау они перестали получать и без того скудный паек и жалование). В течение 2000 г. жители Казаманса несколько раз перекрывали границу в знак протеста. Это угрожало подрывом экономике Гвинеи-Бисау, зависимой от сенегальской таможни, поскольку ряд важных поставок, в том числе продуктов питания, шел с Атлантики и далее - транзитом через Сенегал [3].

В этих условия А. Вад прилагает невероятные дипломатические усилия для налаживания диалога. Одновременно в Бисау происходят выборы, на которых неожиданно для многих побеждает не кандидат от ПАИГК, а демократ Кумба Ялла. В августе 2000 г., сразу после избрания, К. Ялла посетил Дакар, где в качестве жеста доброй воли Абдулай Вад предложил ему улучшение условий для РГБ в совместной разработке нефти. Доход Бисау от будущей нефтедобычи в общей с Сенегалом морской зоне увеличивался с 15 до $20 \%$.

Вновь избранных президентов сближало то, что оба были выходцами из демократической оппозиции, которая и в Сенегале, и в Гвинее-Бисау пришла на смену социалистическому правлению после продолжительного периода политической борьбы. Их личные отношения были подкреплены также отчетливым пониманием общих интересов и недоверием к генералу Мане и его союзникам из ДДСК. Хотя последний и отказался от должности главнокомандующего вооруженных сил в пользу генерала Верисимо Коррейя Сеабра, он оставался влиятельнейшей фигурой в Бисау, особенно, среди военных. Ходили слухи, что А. Мане после победы Кумба Ялла (сам генерал поддерживал на выборах кандидата от ПАИГК) вынашивает планы захвата Зигиншора силами сепаратистов ДДСК и армии Гвинеи-Бисау. В свою очередь К.Ялла стремился укреплять свои позиции в армии путем найма молодых сторонников, в основном, из своей собственной социолингвистической группы - баланте: Мане принадлежал к группе мандинго. (Мы из- бегаем употреблять термин «этническая группа», так как все производные от понятия «этнос» слишком перегружены противоречивыми смыслами [4].) понятия,Противостояние между генералом и президентом закончилось со смертью А. Мане, который погиб во время перестрелки в Бисау 30 ноября 2000 г. при попытке очередного военного переворота. После этого Ялла провел чистку армии от кадров, близких к генералу, и продолжил укрепление связей - политических, экономических и военных - с Дакаром.

Президент Вад в ситуации глубочайшего бюджетного кризиса в РГБ оказывает серьезную поддержку соседней стране - как финансовую, так и дипломатическую, организуя международную помощь. Так, благодаря непосредственному участию Сенегала президенту Ялла удалось в ноябре собрать деньги, чтобы заплатить, наконец, правительству зарплату. Кроме того, А. Вад пытается налаживать прямые связи с армией Бисау путем оказания ей непосредственной помощи и поддержки (финансирование реконструкции военных зданий, открытие в Дакаре госпиталя для гвинейских военнослужащих предоставление необходимого оборудование и материалов). Проблема Казаманса (южной анклавной области Сенегала, тяготеющей к отделению) лежит в основе этой политики Вада. Президент Сенегала рассчитывает с помощью армии Бисау ликвидировать тыловые базы ДДСК и лишить сепаратистов основной опоры.

Ситуация внутри ДДСК благоприятствует намерениям сенегальского президента. После смерти Мане фракция Южного фронта, враждебная лидеру - Салифу Садио (которого поддерживал генерал) - под руководством Леопольда Санья и Сезара Бадиате - инициирует раскол среди повстанцев. Ее поддержали новые военачальники в Бисау, близкие к президенту Ялле. Последним удается договориться с этой частью сепаратистов о совместных действиях против С. Садио. Военные Гвинеи-Бисау начинают войсковую операцию по уничтожению тыловых баз «Атики» на своей территории, а отколовшаяся часть Южного фронта одновременно, с молчаливого согласия Дакара, действует против сторонников Садио в приграничных районах Сенегала [5].

В январе 2001 г. С. Садио направил письмо председателю парламента Гвинеи-Бисау с осуждением нападения гвинейской армии на партизан. Несмотря на официальные опровержения Национальным собранием военных действий, это породило споры между парламентскими фракциями. ПАИГК (в то время - парламентская оппозиция) обратилась к правительству с просьбой выступить посредником в казамансском конфликте, а армию призвала не вмешиваться в политику (что свиде- 
тельствует о квази-независимом участии военных Бисау в этой операции). Военные действия, однако, продолжались. К лету 2001 г. фракция Южного фронта, оппозиционная Салифу Садио, установила контроль над территорией вокруг лагеря близ деревни Кассолол (Kassolol) - на юге Казаманса. Фракция Кассолол не была однородной с самого начала. Ее членов объединяла только вражда с С. Садио [6]. Некоторые хотели продолжать вооруженную борьбу без него, другие, уставшие от бесконечной войны, склонялись к тому, чтобы прекратить боевые действия и пойти на переговоры с центральной властью. Со временем некоторые из ее лидеров установили контакты в Дакаре и были «прикормлены» властью, получая регулярное финансирование в обмен на обещание не нападать на сенегальских военных.

В 2002 г. армия Гвинеи-Бисау усилила давление на сторонников Садио, многие из них подверглись арестам или были депортированы в Сенегал. Многие поселения беженцев из Казаманса были оккупированы и разрушены. Позиции «Атики» в регионе постепенно ослабевают, а Южный фронт перестает быть «горячей точкой» в казамансском конфликте. Так тонкая внешняя политика президента Вада позволила Сенегалу фактически «чужими руками» (силами армии Гвинеи-Бисау и отколовшихся от «Атики» партизан) если не решить окончательно, то на время «затушить» проблему Казаманса.

В сентябре 2003 г. политический альянс Ceнегала и Гвинеи-Бисау, обеспечивший на время стабильность на юге страны, оказался на грани срыва. Главный участник этого альянса от Бисау - президент Кумба Ялла был свергнут 14 сентября военными во главе с начальником Генштаба армии генералом Вериссимо Сеаброй в результате бескровного переворота. Поводом к перевороту послужил очередной перенос президентом «по техническим причинам» парламентских выборов (парламент был распущен еще в 2002 г.).

Однако дипломатический талант Вада и на этот раз сумел развернуть ситуацию в пользу Сенегала. Этому поспособствовали и тесные связи, установленные за время его правления с армией Бисау. Сразу после переворота генерал Сеабра позвонил А. Ваду и заверил, что произошедшее в Бисау ни в коей мере не противоречит интересам Сенегала. Президент Вад решил убедиться в этом лично и прибыл в Бисау в составе посреднической делегации ЭКОВАС совместно с президентами Нигерии и Ганы. Перед международными посредниками стояла непростая задача. С одной стороны, необходимо было поддержать демократически избранного президента, с другой - для всех членов делегации были очевидны антипрезидентские настроения в стране, рост социальной напряженности на фоне глубокого экономического кризиса многомесячные невыплаты зарплат госслужащим и военным и т.д. Компромисс был найден во многом благодаря дипломатическим усилиям президента Сенегала, который встал на защиту путчистов, одновременно оказывая поддержку и свергнутому президенту. В своем выступлении во время встречи Вад приветствовал патриотизм военных Гвинеи-Бисау и сказал, что понимает принятое ими решение положить конец правлению Кумбы Яллы: «Мы видели, что в Гвинее-Бисау военные не получали зарплату в течение шести или девяти месяцев и не поднимали руку на власть». По его мнению, военные вмешались для того, чтобы «остановить неуклонно ухудшающуюся ситуацию». Вад подчеркнул, что к К. Ялле он «относится как к сыну», но при этом согласен, что свергнутый президент РГБ «должен передать власть другим» [7].

В итоге К. Ялле было предложено добровольно сложить полномочия. 18 сентября Кумба Ялла в публичном заявлении объявил о своей отставке, необходимости формирования переходного правительства и призвал военнослужащих «вернуться в казармы». «В интересах нации и во имя мира и национального единства я принял решение отказаться от поста президента Республики... Я настаиваю на незамедлительном формировании переходного гражданского правительства и скорейшем проведении всеобщих выборов», - заявил он [8]. Смена власти была восторженно воспринята населением Гвинеи-Бисау и ознаменовалась массовыми демонстрациями в столице. До формирования переходного правительства функции «временного президента» исполнял В. Сеабра. В конце сентября 2003 г. его полномочия до новых выборов (предполагаемых через 2 года) были переданы 48-летнему экономисту Энрике Рошу. Премьер-министром переходного правительства РГБ был назначен бывший соратник Ялла по «Партии за социальное обновление» - Антонио Артур Санья.

Возобновленный альянс Дакара и Бисау незамедлительно отразился на казамансском фронте. В феврале 2004 г. генерал Сеабра начал новое наступление против «Атики» - на этот раз дальше на восток из пограничной зоны Фуладу, куда отступили партизаны Салифа Садио. Официально операция, вновь предпринятая совместно с фракцией ДДСК Кассолол, была направлена на «защиту гвинейских граждан от бесчинств сепаратистов» [9]. «Бесчинства», вероятнее всего, были инспирированы «дружественными» повстанцами из Кассолол. Дальнейшее наступление на «Атику» армии Гвинеи-Бисау было прервано в марте 2004 г. парламентскими выборами в РГБ, на которых победу одержала партия ПАИГК во главе с Карлосом Гоме- 
сом Жуниором, который становится премьер-министром. Многие представители парламентского большинства когда-то поддержали Мане и С. Садио в ходе «войны 7 июня» и позже были на их стороне против Ялла. Несмотря на победу оппозиционной Дакару партии в конце 2004 г. удача вновь улыбнулась президенту А. Ваду. После убийства генерала Сеабра в октябре 2004 г. Сенегалу удается продвинуть «свою» кандидатуру на пост начальника Генштаба РГБ. Им становится генерал Батиста Тагме На Вай, который в 2001 г. возглавлял наступление на Садио. В феврале 2005 г. На Вай прибыл в Дакар для «укрепления военного сотрудничества между Сенегалом и Гвинеей-Бисау» и был принят лично Абдулаем Вадом. Через месяц Дакар в качестве поддержки отправляет транспорт и военную технику в армию Гвинеи-Бисау. По этому случаю генерал На Вай заявляет, что «сделает все, чтобы восстановить порядок и спокойствие на границе между двумя странами» [10].

Восстановление гражданской власти в Гвинее-Бисау после переворотов 2003 и 2004 гг. позволило в 2005 г. двум бывшим президентам Ялла и Виейра - вновь вернуться на политическую арену в преддверии президентских выборов. В апреле 2005 г. Виейра эффектно прибыл на родину на военном вертолете из Гвинеи-Конакри. До этого президент этой страны Лансана Конте, который был личным другом Виейры, устроил в Канакри совещание, пригласив Виейру и высшее военное руководство Бисау. При посредничестве Л. Конте была достигнута договоренность о возвращении Ж. Виейры в Гвинею-Бисау - военные гарантировали ему обеспечение безопасности. Дакар, казалось, остался в стороне от этого маневра, но А. Вад не мог не понимать всю его значимость. И хотя президент Сенегала по-прежнему поддерживал на выборах К. Ялла (в том числе и финансово), он отчетливо понимал: «поставив на одну лошадь», есть большой шанс проиграть. Поэтому Виейра становится альтернативной кандидатурой, которую готов поддержать Дакар. Третьим вероятным кандидатом на выборах выступает Малам Бакай Санья - его поддерживает ПАИГК. Этот последний вариант был наименее выгоден Дакару, так как «носил клеймо» своего бывшего союза с генералом Мане в «войне 7 июня».

В формировании нового альянса между А. Вадом и Ж. Виейрой большую роль сыграл предприниматель из Казаманса Пьер Гудиабу - близкий родственник Виейры и значимая фигура в западноафриканской дипломатической игре. П. Гудиабу долгое время был советником президента Вада по управлению ситуацией в Казамансе. Все свидетельствует о том, что успешная избирательная кампания Виейры напрямую связана с матери- альной поддержкой Сенегала. Кроме того, именно сенегальский президент и П. Гудиабу помогли ему получить помощь и от других африканских лидеров. Связанный с обоими кандидатами - Ялла и Виейра, президент Вад сыграл решающую роль на президентских выборах в РГБ 2005 года. Когда Кумба Ялла отказался принять третье место в первом туре, А. Вад отправил за ним свой личный самолет и убедил не только согласиться с результатами выборов, но и поддержать Ж. Виейру, тем самым способствуя победе последнего [11]. Вскоре после выборов и победы Ж. Виейры президент Вад по его просьбе организует «изгнание» К. Ялла в дружественный Сенегалу Морокко. Кроме того, После такой поддержки вновь избранный президент РГБ Ж. Виейра, естественно, заверил сенегальского лидера, что «готов сделать все от него зависящее, чтобы решить конфликт в Казамансе». Это заявление активно приветствовала сенегальская пресса [12]. В дальнейшем Сенегал продолжает поддерживать армию Гвинеи-Бисау поставками продовольствия, военной техники и транспортных средств. Таким образом, после выборов 2005 г. у Дакара образовались два рычага влияния в РГБ начальник Генштаба (На Вай) и президент.

В марте 2006 г. войска Гвинеи-Бисау под руководством племенника На Вая - полковника Антониу Инждаи проводят решающую операцию по «зачистке» баз и сторонников С. Садио на своей территории В результате более 2 тыс. человек (среди которых, главным образом, мирные жители) бежали через границу в Сенегал [13]. Войско С. Садио было разгромлено, базы уничтожены, сам лидер повстанцев «Атики» отошел на север Казаманса, где в апреле 2006 г. бои были продолжены уже с сенегальской армией и Северным фронтом, выступившими в альянсе (подробнее см. Гл. 4). Более 60 солдат армии РГБ подорвались на минах, заложенных сепаратистами перед отступлением [14]. Это новое наступление на казамансских партизан было подвергнуто критике общественностью и парламентской оппозицией Гвинеи-Бисау, спровоцировав очередной парламентский скандал. Генерал На Вай обвинил некоторых депутатов в связях с ДДСК, был задержан бывший министр, одного депутата лишили мандата [15]. Для Сенегала в проблеме Казаманса надолго наступило затишье.

В 2009 г. Гвинея-Бисау пережила очередной военный переворот. В результате теракта 1 марта в здании штаб-квартиры армии был взорван начальник Генштаба Тагме На Вай. Его сторонники в армии возложили ответственность за его гибель на президента страны Ж. Виейру. В Бисау начались уличные беспорядки. 2 марта солдаты, верные погибшему начальнику штаба, атаковали президентский дворец - президент Жуан Бернарду Ви- 
ейра был застрелен ими при попытке покинуть здание. Ситуация вновь обострилась в июне, когда были убиты два человека, близких к Виейре бывший министр обороны Проенса и министр внутренней администрации Бакиро Дабо. Вооруженные силы и правительство Гомеша Жуниора обвиняли убитых в подготовке государственного переворота и намекали на причастность к этому сенегальских властей. Эти подозрения не могли не отразиться самым негативным образом на дальнейших отношениях Дакара с Бисау, тем более в ситуации, когда все связи с РГБ, налаженные Вадом, оказались оборваны. Сенегал в одночасье лишился двух своих креатур в руководстве соседней страны, и это немедленно отразилось на обстановке в Казамансе, где после долгого затишья вновь активизировались повстанцы.

На внеочередных президентских выборах в Гвинеи-Бисау в июле 2009 г. победил кандидат от ПАИГК - Малам Бакай Санья. Будучи бывшим сторонником Мане и оппонентом Дакара, М. Санья, однако, к 2009 г. сблизился с А. Вадом и во время выборов активно искал его поддержки. По слухам, ранее он даже принял суфийскую веру президента Вада, примкнув к братству Муридийя. Накануне выборов Санья нанес визит в Дакар и заявил сенегальским СМИ, что А. Вад является его «отцом» и «одним из самых важных фигур в современной истории Африки». М. Санья обещал также в случае своего избрания «работать вместе» с президентом Сенегала [16]. Как и во время предыдущих избирательных кампаний в Бисау А. Вад оказывал прямую материальную поддержку будущему президенту и способствовал его победе на выборах.

Политика Сенегала в Бисау в первой половине 2000-х гг. поддерживалась сильным экономическим и культурным влиянием и была похожа в некоторых аспектах на политику Франции по отношению к ее африканским партнерам (бывшим колониям, в том числе - Сенегалу) [17] . Эта политика включала сильный элемент патронажа и выражалась в военном сотрудничестве, предоставлении доступа к медицинской помощи, дипломатических и брокерских услугах, финансовой поддержке «своих» кандидатов на выборах и т.д.

\section{Ослабление сенегальского влияния в Бисау в конце 2000-х гг. Современные тенденции сенегало-гвинейских отношений}

Начиная с 2009 г. отношения двух стран становятся все более сложными. Смерть президента Виейры привела к политическому подъему Гомеша Жуниора - процветающего бизнесмена, который имел тесные связи с Португалией, и его близкого соратника - молодого офицера - Замора Индута, в прошлом человека генерала Мане. Первый стал премьер-министром в правительстве еще при Виейре (в январе 2009 г.), второй был назначен начальником Генштаба армии Бисау после смерти президента. Эти кадровые перестановки нанесли серьезный удар по сенегальскому влиянию в РГБ и лишили Дакар основного инструмента управления казамансским конфликтом. По неофициальной информации, после смены власти в Бисау некоторые из военных РГБ возобновили продажи оружия сепаратистам Казаманса.

В марте 2009 г. Индута подписал соглашение о военном сотрудничестве с президентом Гамбии Яйя Джамме, чьи сложные отношения с Дакаром и связи с Салифом Садио были хорошо известны. В октябре 2009 г. власти Бисау развернули войска в ответ на пограничные разногласия в районе Варела, такая же реакция последовала на незаконное проникновение на территорию РГБ сенегальских рыбаков. Эти инциденты заставили власти Сенегала, столкнувшиеся с независимым поведением соседней страны, искать новые пути для установления своего влияния в РГБ. Надежда на президента М. Санью не оправдалась, поскольку из-за серьезной болезни (диабет), его влияние в стране весь период правления (до смерти в 2012 г.) оставалось незначительным.

Некоторое оживление отношений двух стран происходит в 2011 г. Этот период отмечен ростом напряженности между президентом Санья и премьер-министром Г. Жуниором. Сенегал, казалось, смирился с потерей своего влияния и пытался приблизиться к Г. Жуниору, предлагая дипломатическую поддержку в получении РГБ международной финансовой помощи. В феврале 2011 г. Гомес Жуниор нанес свой первый официальный визит в Дакар, заручившись поддержкой А. Вада. Сенегал также пытался восстановить связь с армией Гвинеи-Бисау. В конце июня 2011 г. начальники штабов двух стран подписали соглашение в Бисау, после чего Гвинея-Бисау пообещала «арестовать всех бунтовщиков, укрывшихся на ее территории» [18]. В сентябре того же года сенегальский и гвинейский командиры пограничной зоны встретились в Кольде, на востоке Казаманса. Была достигнута договоренность о создании совместных патрулей на границе. На этом новом этапе Дакар мог, по крайней мере, рассчитывать на определенный уровень военного сотрудничества, хотя об использовании армии Гвинеи-Бисау в борьбе с ДДСК, как это было в 2001-2009 гг. уже не могло быть и речи.

В целом, начиная с конца 2000-х гг. влияние Дакара в РГБ заметно ослабевает. На фоне укрепившейся экономики Гвинея-Бисау, ранее во всем зависимая от Сенегала, может себе позволить диверсифицировать международные связи. Все боль- 
ший интерес к этой стране проявляет Ангола. Постепенно Ангола, будучи основным партнером и защитником премьер-министра Гомеша Жуниора (представлявшего реальную силу в РГБ), принимает на себя, вместо Сенегала, основные рычаги власти и влияния в Гвинее-Бисау. В Бисау уже много легальных и нелегальных мигрантов из этой страны. Символично, что во время попытки государственного переворота в декабре 2011 г. Г. Жуниор укрывался от мятежников именно в ангольском посольстве.

Весной 2012 г. и Сенегал, и Гвинея-Бисау стояли на пороге президентских выборов. В Сенегале 25 марта победил представитель оппозиции, бывший премьер-министр и соратник Вада Маки Салль. В Бисау 18 марта Гомеш Жуниор получил $49 \%$ голосов в первом туре и уверенно шел к победе. Второе место занял оппозиционер, лидер Партии социального обновления Мохаммед Ялла (бывший президент Кумба Ялла, взявший себе в 2008 г. мусульманское имя). Ялла заявил о массовых фальсификациях и отказался признать результаты первого тура выборов. Однако второй тур, намеченный на 29 апреля, не состоялся не по этой причине. Электоральный процесс был прерван 12 апреля очередным военным переворотом в Бисау.

Группа военных во главе с Мамаду Туре Курума арестовала Г. Жуниора, обвинив его в связях с Анголой и заговоре против национальной армии. Впоследствии, его (и временного президента страны освободили и перевезли в Кот-д’Ивуар. При поддержке основных оппозиционных партий военные утвердили временное правительство, которое свергнутый кандидат в президенты и парламентское большинство ПАИГК отказались признать.

Наряду с Нигерией, Буркина-Фасо и Котд’Ивуаром - другими странами ЭКОВАС, также недовольными усилением влияния Анголы в Западной Африке, Сенегал поддержал военный переворот. Ангола и Португалия в этой ситуации открыто обвинили страны ЭКОВАС в его организации и потребовали признания результатов первого тура выборов и продолжения избирательного процесса. Ангола даже попыталась ввести свои войска в Биcay, но они были встречены «в штыки» военными РГБ. В итоге ЭКОВАС ввел свой миротворческий контингент (600 чел.), в составе которого были и военные сенегальской армии. Под давлением военных армии РГБ ангольские войска были вынуждены покинуть Бисау. Таким образом, через 13 лет после окончания операции «Габу» сенегальские военные вновь оказались в Гвинее-Бисау. Правда, на этот раз они были хорошо приняты гвинейской армией. Вместе с некоторыми ключевыми партнерами по ЭКОВАС Сенегал вновь оказался вовлечен в урегулирование политического кризиса в соседней стране. Это давало шанс восстановить былые связи с РГБ. Хотя переходный президент Гвинеи-Бисау и нанес свой первый дипломатический визит Дакару 14 июня 2012 г., перспективы дальнейшего сотрудничества двух стран оставались неясными.

В начале 2014 г. после задержания сенегальскими военными российского рыболовецкого траулера «Олег Найденов» отношения между двумя странами вновь осложнились [19]. Судно было захвачено 4 января путем «вооруженной атаки» сотрудниками спецслужб Сенегала в территориальных водах Гвинеи-Бисау, где вело рыбный промысел согласно контракту. На борту траулера в момент его задержания находились 23 гражданина этой страны, с которыми сенегальские военные вели себя особенно жестко. Власти Гвинеи-Бисау, возмущенные этим инцидентом, объявили о разрыве отношений с Сенегалом в области рыболовства [20]. На следующий день береговая охрана Гвинеи-Бисау задержала несколько сенегальских рыболовецких лодок, чтобы заставить власти Сенегала освободить своих моряков, задержанных вместе с россиянами. В результате министру рыбного хозяйства Сенегала пришлось лично приехать в соседнюю страну, чтобы урегулировать конфликт. Кроме того, правительство Бисау заявило о создании комиссии для расследования обстоятельств и проверки законности задержания «Олега Найденова». В состав комиссии вошли главы министерств иностранных дел, внутренних дел, обороны и здравоохранения Республики. В официальном заявлении правительства сообщалось, что после захвата российского судна сенегальскими военными были избиты морские наблюдатели Гвинеи-Бисау, находившиеся на борту, и подчеркивалось, что «подобные действия Сенегала являются грубым нарушением международных законов и не способствуют поддержанию мирного и добрососедского климата между соседними государствами» [21].

Текущие политические процессы в Гвинее-Бисау обещают вновь усилить напряженность в отношениях Сенегала с южным соседом. Избрание на пост президента РГБ в мае 2014 г. кандидата от ПАИГК Жозе Марио Ваза вызвало большое беспокойство у лидера Сенегала Маки Салля. Бывший министр финансов Жозе Ваз легко обошел соперников в первом туре с результатом в $41 \%$ голосов, а во втором туре 18 мая - победил, набрав $62 \%$ голосов избирателей [22]. Опасения сенегальского президента, согласно информации французского еженедельника «Jeune Afrique», вызывает проангольская ориентация нового лидера Гвинеи-Бисау и, особенно, его тесные связи с Движением демократических сил Казаманса, с лидерами которого Маки Салль пытается договориться в течение двух 
лет своего правления. После избрания Ваза все усилия по достижению мирного соглашения с сепаратистами при одновременном сохранении территориальной целостности Сенегала могут «пойти прахом» [23].

\section{Резюме}

После кризиса конца 1990-х гг. во взаимоотношениях Сенегала и Гвинеи-Бисау происходил планомерный подъем. 2000-2007 гг. (первый президентский срок А. Вада) отмечены ростом влияния Сенегала в соседней стране. Это был период сильнейшего экономического кризиса и международной изоляции РГБ после «войны 7 июня». Сенегал, напротив, находился тогда на экономическом и политическом подъеме.

Мастер дипломатической игры, президент Вад использовал международную маргинализацию РГБ для установления всеобъемлющего влияния Сенегала на ее политику и экономику. Главной задачей А. Вада было решение проблемы Казаманса, что было невозможно без всестороннего привлечения Гвинеи-Бисау, на территории которой располагались тыловые базы повстанцев, имевших теснейшие связи с населением РГБ. Пиком этого влияния стал 2006 г., ознаменовавшийся победо- носным выступлением армии Бисау против главного бунтаря в Казамансе - Салифа Садио.

Начиная с 2007 г. (второй президентский срок Вада) гегемония Сенегала в Гвинее-Бисау начинает постепенно ослабевать. С гибелью в марте 2009 г. двух его ключевых гвинейских союзников - Ж. Виейры и Т. На Вая Сенегал утрачивает основные связи и рычаги своего влияния в соседней стране. ГвинеяБисау диверсифицирует международные отношения и переориентируется на Анголу и Португалию.

В ближайшей перспективе отношения двух стран обещают быть достаточно сложными. Новый президент Сенегала Маки Салль, не обладающий дипломатическими талантами своего предшественника, вряд ли сумеет восстановить утраченные связи с политической и военной верхушкой РГБ. Это тем более затруднительно сейчас, когда Гвинея-Бисау вновь вступила в полосу военных переворотов, и политические лидеры здесь все время меняются. Между тем, властям Сенегала придется продолжать искать пути для сближения с РГБ изза «вечного» конфликта центральной власти с полуанклавной южной областью (Казамансом). Поскольку любое отчуждение с Гвинеей-Бисау всегда может спровоцировать новую волну сепаратизма в Казамансе, культурно и политически ориентированном больше на Бисау, чем на Дакар.

\section{Библиография:}

1. Хабенская Е.О. Сенегал и Гвинея-бисау сквозь призму казамансского конфликта (1959-1998 гг.) // Геополитический журнал. Октябрь, 2015. № 4 (11). С. 46-57.

2. Филиппова Е., Филиппов В. Государство и общество перед лицом социального кризиса (две парадигмы: российская и французская) // Этническая ситуация и конфликты в странах СНГ и Балтии / Ежегодный доклад Сети этнического этнологического мониторинга и раннего предупреждения конфликтов. 2005. Москва, 2006. С. 12-25.

3. Сенегал и Гвинея-Бисау сняли блокаду границы // ИТАР-ТАСС. 2000. 4 августа. (http://www.info.itar-tass.com)

4. Филиппов B.P. Советская теория этноса. Историографический очерк. М., 2010.

5. Vingt-quatre maquisards casamançais tués dans le nord de la Guinée-Bissau // AFP. 8 January 2001.

6. Foucher V. Pas d'Alternance en Casamance? // Politique Africaine. 2003. N 3 (91). Р. 115.

7. Военная хунта назначила временного президента и премьер-министра Гвинеи-Бисау // ИНФО-ТАСС. 2003. 24 сентября. (http://info.itar-tass.com)

8. Политическая обстановка в Гвинее-Бисау после военного переворота // ИНФО_ТАСС. 2003.18 сентября. (http:// info.itar-tass.com)

9. Foucher V. Wade's Senegal and its Relations with Guinea-Bissau: Brother, Patron or Regional Hegemon? // SAIIA (South African Institute of International Affairs) Occasional Paper. N 132. January 2013. P. 10.

10. Don d'équipements du Sénégal à l'armée bissau-guinéenne // PANA (Pan-African News Agency). 1 March 2005.

11. Ousted Guinea-Bissau president flown to Senegalfor talksahead of crucial poll // BBC Monitoring Africa. 23 May 2005.

12. Nino Vieira président, un atout pour la paix en Casamance // Wal Fadjri. 25 July 2005; French radio interviews GuineaBissau President-elect Joao Vieira // BBC Monitoring Africa. 22 September 2005.

13. 178 réfugiés bissau-guinéens sont arrives à Ziguinchor // PANA (Pan-African News Agency). 23 March 2006.

14. Près de 60 soldats bissau-guinéens tués par le MFDC // PANA (Pan-African News Agency). 1 April 2006.

15. L'ancien minister de l'Intérieur de la Guinée-Bissau arête // PANA (Pan-African News Agency). 3 April 2006

16. Foucher V. Wade's Senegal and its Relations with Guinea-Bissau: Brother, Patron or Regional Hegemon? // SAIIA (South African Institute of International Affairs) Occasional Paper. N 132. January 2013. P. 14.

17. Филиппов B.P. Политика Франции в Камеруне // Политика и общество. 2015. № 4. С. 531-542.

18. Foucher V. Wade's Senegal and its Relations with Guinea-Bissau: Brother, Patron or Regional Hegemon? // SAIIA (South African Institute of International Affairs) Occasional Paper. N 132. January 2013. P. 15.

19. Хабенская Е. «Олег Найденов»: генезис драмы в Атлантике // InfoRos.ru. 20 февраля 2014. (http://inforos.ru/ru/? module=news\&action=view\&id=36948)

20. Гвинея-Бисау разорвала отношения с Сенегалом в области рыболовства // Известия. 5 января 2014. (http:// izvestia.ru/news/563620) 
21. Гвинея-Бисау создала следственную комиссию по задержанию российского траулера «Олег Найденов» // ИТАРTACC. 2014. 10 января (http://www.info.itar-tass.com)

22. Экс-министр финансов Гвинеи-Бисау победил на президентских выборах // РИА Новости». 20 мая 2014 . (http:// ria.ru/world/20140520/1008599509.html)

23. Sénégal: Macky Sall préoccupé par l'issue du scrutin bissau-guinéen // Jeune Afrique. 2014. 20 Mai. (http://www. jeuneafrique.com/Article/JA2784p006.xml10/)

24. Манойло А.В. Парадигмы управления международными конфликтами: конкуренция или конфронтация. // Национальная безопасность / nota bene. 2011. № 5. С. 135-142.

25. Манойло А.В. Мирное разрешение международных конфликтов: национальные концепции, модели, технологии. // Власть. 2008. № 8. С. 79-83.

\section{References (transliterated):}

1. Khabenskaya E.O. Senegal i Gvineya-bisau skvoz' prizmu kazamansskogo konflikta (1959-1998 gg.) // Geopoliticheskii zhurnal. Oktyabr', 2015. № 4 (11). S. 46-57.

2. Filippova E., Filippov V. Gosudarstvo i obshchestvo pered litsom sotsial'nogo krizisa (dve paradigmy: rossiiskaya i frantsuzskaya) // Etnicheskaya situatsiya i konflikty v stranakh SNG i Baltii / Ezhegodnyi doklad Seti etnicheskogo etnologicheskogo monitoringa i rannego preduprezhdeniya konfliktov. 2005. Moskva, 2006. S. 12-25.

3. Senegal i Gvineya-Bisau snyali blokadu granitsy // ITAR-TASS. 2000. 4 avgusta. (http://www.info.itar-tass.com)

4. $\quad$ Filippov V.R. Sovetskaya teoriya etnosa. Istoriograficheskii ocherk. M., 2010.

5. Vingt-quatre maquisards casamançais tués dans le nord de la Guinée-Bissau // AFP. 8 January 2001.

6. $\quad$ Foucher V. Pas d'Alternance en Casamance? // Politique Africaine. 2003. N 3 (91). P. 115.

7. Voennaya khunta naznachila vremennogo prezidenta i prem'er-ministra Gvinei-Bisau // INFO-TASS. 2003. 24 sentyabrya. (http://info.itar-tass.com)

8. Politicheskaya obstanovka v Gvinee-Bisau posle voennogo perevorota // INFO_TASS. 2003. 18 sentyabrya. (http://info. itar-tass.com)

9. Foucher V. Wade's Senegal and its Relations with Guinea-Bissau: Brother, Patron or Regional Hegemon? // SAIIA (South African Institute of International Affairs) Occasional Paper. N 132. January 2013. P. 10.

10. Don d'équipements du Sénégal à l'armée bissau-guinéenne // PANA (Pan-African News Agency). 1 March 2005.

11. Ousted Guinea-Bissau president flown to Senegalfor talksahead of crucial poll // BBC Monitoring Africa. 23 May 2005.

12. Nino Vieira président, un atout pour la paix en Casamance // Wal Fadjri. 25 July 2005; French radio interviews GuineaBissau President-elect Joao Vieira // BBC Monitoring Africa. 22 September 2005.

13. 178 réfugiés bissau-guinéens sont arrives à Ziguinchor // PANA (Pan-African News Agency). 23 March 2006.

14. Près de 60 soldats bissau-guinéens tués par le MFDC // PANA (Pan-African News Agency). 1 April 2006.

15. L'ancien minister de l'Intérieur de la Guinée-Bissau arête // PANA (Pan-African News Agency). 3 April 2006.

16. Foucher V. Wade's Senegal and its Relations with Guinea-Bissau: Brother, Patron or Regional Hegemon? // SAIIA (South African Institute of International Affairs) Occasional Paper. N 132. January 2013. P. 14.

17. Filippov V.R. Politika Frantsii v Kamerune // Politika i obshchestvo. 2015. № 4. S. 531-542.

18. Foucher V. Wade's Senegal and its Relations with Guinea-Bissau: Brother, Patron or Regional Hegemon? // SAIIA (South African Institute of International Affairs) Occasional Paper. N 132. January 2013. P. 15.

19. Khabenskaya E. «Oleg Naidenov»: genezis dramy v Atlantike // InfoRos.ru. 20 fevralya 2014. (http://inforos.ru/ru/?mod ule=news\&action=view\&id=36948)

20. Gvineya-Bisau razorvala otnosheniya s Senegalom v oblasti rybolovstva // Izvestiya. 5 yanvarya 2014. (http://izvestia. $\mathrm{ru} / \mathrm{news} / 563620$ )

21. Gvineya-Bisau sozdala sledstvennuyu komissiyu po zaderzhaniyu rossiiskogo traulera «Oleg Naidenov» // ITAR-TASS. 2014. 10 yanvarya (http://www.info.itar-tass.com)

22. Eks-ministr finansov Gvinei-Bisau pobedil na prezidentskikh vyborakh // RIA Novosti». 20 maya 2014. (http://ria.ru/ world/20140520/1008599509.html)

23. Sénégal: Macky Sall préoccupé par l'issue du scrutin bissau-guinéen // Jeune Afrique. 2014. 20 Mai. (http://www. jeuneafrique.com/Article/JA2784p006.xml10/)

24. Manoilo A.V. Paradigmy upravleniya mezhdunarodnymi konfliktami: konkurentsiya ili konfrontatsiya. // Natsional'naya bezopasnost' / nota bene. 2011. № 5. S. 135-142.

25. Manoilo A.V. Mirnoe razreshenie mezhdunarodnykh konfliktov: natsional'nye kontseptsii, modeli, tekhnologii. // Vlast'. 2008. № 8. S. 79-83. 